\title{
Factors Affecting the Enactment of Small Scale Businesses within Pastoral Community in Ethiopia Somali Region at Liban zone (Specifically in Dolo Ado and Filtu District)
}

\author{
Addisu Tesema Tanga \\ Lecturer at College of Business and Economics, Specifically in Department of Management, in Wolaita sodo \\ University, Ethiopia
}

\begin{abstract}
The general objective of this study aimed to assess factors affecting the enactment of small scale businesses within pastoral community in Ethiopia Somali region at Liban zone (specifically in dolo ado and filtu district).To achieve the objectives, the study used non-probability sampling techniques because this technique is much less complicated, less expensive, and moreover it is very convenient in the situation when the sample to be selected is very small and the researcher wants to get some idea of the population characteristics. Out of total (323) population, 180 (56\%) of Small scale Business owners that are engaged in different business activities have been selected judgmentally (Purposively) as sample from both districts (dolo ado and Filtu). In this study both primary and secondary sources have been used. The dominant tool used for data collection in this study was questionnaire that is scheduled and designed for gathering primary data only from licensed owners of Small scale businesses within pastoral community. The secondary data was also collected from the trade and transport department of Dolo ado and Filitu districts and also from books, magazines, and others written documents such as directives, legal codes, the country growth plan and other pertinent materials guiding the small Scale businesses. For the reason that, its simplicity and clarity for drawing the reference, the descriptive analysis has been used. In the course of data analysis, the data were analyzed both quantitatively using percentile and qualitatively through document narration. The existence of high family dependency on small scale businesses has been observed as a major hold back factors for the businesses not to upgrade themselves to the middle and large Scale businesses. As depicted on the finding, the owners and employees of small scale businesses have no managerial skills and entrepreneurial ability to run their businesses. The research revealed that, there is influence on small scale businesses from government side and also there is high taxation both on existing and newly started businesses. Lack of adequate finance and absence of appropriate supporting agencies are the major problems for small scale businesses. Therefore, the government bodies and agencies would advise to provide reasonable source of finance, capacity building training, and also to collect fair tax both from existing and newly established businesses. On the other side, the owners of small scale businesses would recommend to diversify their sources of income in order to minimize the impact of family dependency on their business.
\end{abstract}

Keywords: SSB, Factors, Enactment, pastoral community, Liban zone

DOI: $10.7176 / \mathrm{EJBM} / 12-4-04$

Publication date: February $29^{\text {th }} 2020$

\section{Introduction}

\subsection{Back Ground of The Study}

In different fields such as economics and business management as small scale business is a Business that has relatively small share of its market and managed by its owners or parts. Small scale business play great role in any society and they involve in the provision of goods and services that would address the need of few people that generally go unnoticed by large scale businesses or which are unprofitable for large firms. Small scale business can be service rendering firms; manufacturing organizations, merchandise business enterprises and some others related business. This research focuses on factors affecting the enactment of small scale businesses within pastoral community in Ethiopia Somali region at Liban zone (specifically in dolo ado and filtu district).

Small scale businesses are businesses which are likely operating in a single market or limited range of markets or offering a limited range of product or service. This means that the scope of firms operation is limited and has less strategic issues than in large scale businesses. Small scale businesses are not homogeneous in their nature rather each is different and has special characteristics, i.e. highly diverse with respect to structural characteristics, age, growth rate, industrial sector, and financing conditions.

\subsection{Statement of the Problem}

Small scale businesses have an abundant part to play in the economy of the country and the owners of small scale business are most of the time an individual who established and manages the business. Previous research conducted by Abebayehu Taye (June2016), Gemechu Abdissa \& Teklemariam Fitwi (2016) and others researches depicted that on their finding marketing factors as a major challenge for small scale businesses. These 
marketing factors are: inadequacy of market, difficulty of searching new market, lack of demand forecasting, lack of market information and absence of relationship with an organization/association. Hence, this study aims at assessing hindering factors of the small scale business not to upgrade them to middle and large Scale businesses and others different factors which affect small scale businesses not to be successful and effective in their operations, which other researchers fail to address, in case of Somali region at Liban zone (specifically in dolo ado and filtu district).

\subsection{Objective Of the Study}

\subsubsection{General Objectives}

The general objective of the study is to assess factors affecting the enactment of small scale businesses within pastoral community in Ethiopia Somali region at Liban zone (specifically in dolo ado and filtu district).

\subsubsection{Specific objectives}

$>$ To assess the factors that affects the profitability of Small scale business within pastoral community.

$>$ To identify the effect of managerial skill and entrepreneurial ability of the owners in the operation of small scale business.

$>$ To assess the factors that hinders the small scale business not to upgrade them to middle and large Scale business.

$>$ To assess the impact of marketing and market situations in small scale business.

$>$ To study the government norms related to the small scale business within pastoral community.

$>$ To assess the financial capacity and capital seeking of owners of small scale business within pastoral community.

$>$ To assess the impact of infrastructure on the operation of small scale business.

$>$ To make suggestion to overcome the problems and factors that related to small scale business.

\subsection{Significance Of the Study}

This study has enormous positive influence on the researcher in terms of enhancing the knowledge of understanding to explore the factors that affecting the enactment of small scale businesses within pastoral community in Ethiopia Somali Region, Liban zone. In addition, this research gave some suggestion and recommendation for solving the problems and factors obtained on the findings from the result of the analysis.

\subsection{Scope Of the Study}

Shortage of resource and Lack of time forced the researcher to address only in assessment of factors that affect the enactment of small scale businesses within pastoral community in Ethiopia Somali region at Liban zone (specifically in dolo ado and filtu district)..

\subsection{Limitation Of The Study}

While conducting this study we faced different kind of problems. The main problems are financial and time resources. This research has the following limitation relating to other primary and secondary sectors. The allocated time for data collection is not enough to drive sufficient information through personal observation. Shortages of literature and reference materials were also the major constraints during conducting the study.

\section{Methodology of the Study}

\subsection{Introduction}

In this study under this part, the researcher tried to outline the description of the study areas/Location, the design of the research, approach of the study, the sampling design, sampling technique, data sources, tools used for data collection and method of data analysis.

\subsection{Description of the Study Area}

The study conducted in Ethiopia Somali region at Liban zone (specifically in dolo ado and filtu district).The Somali regional state is the largest and eastern most of the nine regions of Ethiopia. The state borders the Ethiopian states of Afar and Oromia and the chartered city of Dire Dawa to the west, as well as Djibouti to the north, Somalia to the north, east, and south; and Kenya to the southwest. Jigjiga is the capital city for Somali regional state and it became the capital of Somali region in 1995 after it was moved from Godey. The city located in faafan zone with $60 \mathrm{Km}$ west of the border with Somalia and $611 \mathrm{~km}$ from Addis Ababa the capital city of Ethiopia. The city has an elevation of 1,609 meters above sea level and Location within Ethiopia coordinates $9^{\circ} 21^{\prime} \mathrm{N} 42^{\circ} 48^{\prime} \mathrm{E} / 9.350^{\circ} \mathrm{N} 42.800^{\circ} \mathrm{E}$. Somali Regional state covers the total Area of $327,067 \mathrm{~km}^{2}$ and the region has eleven subdivided Administrative zones i.e (Afder, Dollo, Erar, Dawa, Fafan, Jarar, Korahe, Liben, Nogob, shebelle and Sitti). The study conducted only in Liban zone among from the Administrative zones. 
Liban zone is bordered on the south by Kenya, on the Northwest by the Oromia region, on the Northeast by Afder and on the southeast by Somalia. This zone has various Social and economic ties with Somalia and adjacent Somali populated north eastern Province of Kenya. Based on the 2007 census conducted by the central statistical Agency of Ethiopia (CSA) this zone has a total population of 339,821 of whom 197,315 are men and 142,506 are women. Liban zone has seven administrative Districts i.e (Dolo ado, Qadhaadhumo, Hudet, Moyale, Gaduud, Filtu and Bander).Therefore; in this study the two districts i.e (Dolo ado and Filtu) has been selected as research areas because of these two districts have heavily settled pastoralist community who engaged in Small scale business are more available relative with other Districts in Liban zone.

\subsection{Research Design}

The study was employed a descriptive research design. The main Purpose for using this design was due to the fact that this design was supposed to help to briefly assess the major factors that affect Small scale business along with the future prospects. Furthermore, this design helped to briefly explain, other than simply describing the existing performance of the small scale business.

\subsection{Sampling Technique}

The study used non-probability sampling techniques because this technique is much less complicated, less expensive, and the researcher would have advantage of the available respondents without the statistical complexity of the probability sampling. Moreover it is very convenient in the situation when the sample to be selected is very small and the researcher wants to get some idea of the population characteristics. Thus, in this study Non-probability sampling techniques is used and mainly Judgmental (Purposive or deliberate) sampling has been implemented in order to select the samples both from Dolo ado and Filtu Districts.

\subsection{Population and Sample size}

According to the information gathered from both Districts trade and Transport Bureau, the total populations that are licensed and engaged in Small scale business are 323 out of them 178 (55\%) are from Dolo ado and 145 $(45 \%)$ are from Filtu district. However, there are also Small scale businesses that are not been accredited and licensed by trade and Transport Bureau of both districts, but in this study only the Licensed and accredited Small scale businesses have been considered during sample selection. Here from the total population $180(56 \%)$ of Small scale Business owners that are engaged in different businesses activities have been selected judgmentally (Purposively) as sample from both districts.

\subsection{The Sources of data and method of data gathering}

In this study both primary and secondary sources have been used. The dominant tool used for data collection in this study was questionnaire that is scheduled and designed for gathering primary data only from licensed owner of Small scale businesses within pastoral community. The secondary data was also collected from the trade and transport department of Dolo ado and Filitu districts and also from books, magazines, and others written documents such as directives, legal codes, the country growth plan and other pertinent materials guiding the small Scale businesses.

\subsection{Method of Data analysis}

During the data processing, the study has used the following data processing steps, such as editing and classification of the collected row data. For the reason that, its simplicity and clarity for drawing the reference, the descriptive analysis has been used. In the course of data analysis, the data were analyzed both quantitatively using percentile and qualitatively through document narration.

\section{Data Interpretation and Analysis}

The results of the data collected and analyzed are presented in the following manner. One thing that should be kept in mind is that the data obtained through questionnaire, personal observation and secondary data have given the researchers an opportunity to arrive at the conclusions that derived from the findings. 
Chart 1:- Sex of respondents

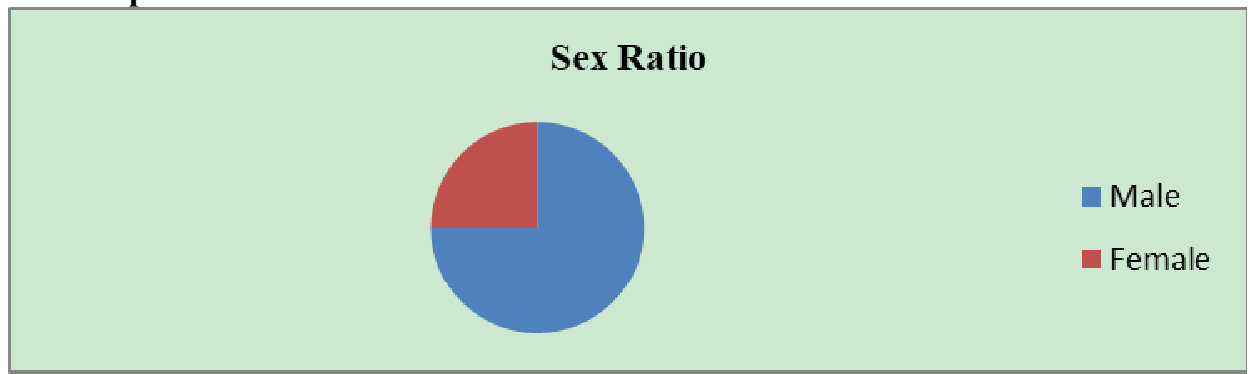

Source: Own survey (2018)

As shown in the chart 1 , from the total sample surveyed $135(75 \%)$ respondents are males and the rest of $45(25 \%)$ are females. It can be viewed from this result, the participation of males exceed that of females in running small scale business within pastoral Community.

Figure 1:- Age Distribution

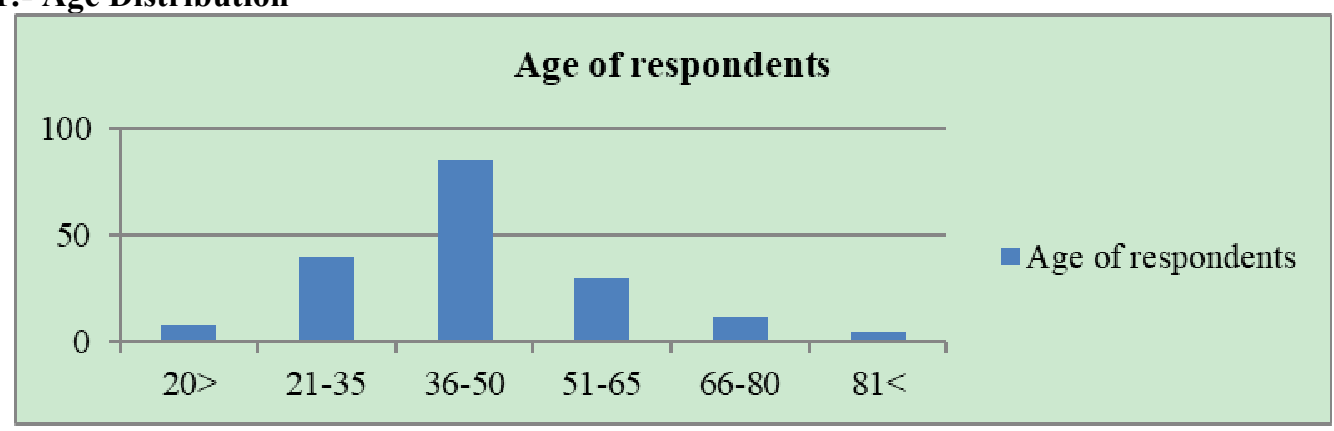

Source: Own survey (2018)

The result of the data analysis presented in the above bar chart revealed that the majority (85) $47.2 \%$ respondents lie within the age category of 36 to 50 years, the next highest number (40) $22.2 \%$ of the respondents lie within the age category of 21 to 35 years and the third highest number (30) $16.7 \%$ of small scale business owner's age lie within the age category of 51 to 65 years. Hence, the majority of respondents are middle-aged adults.

Figure 2:- Marital Status of SSB Owners

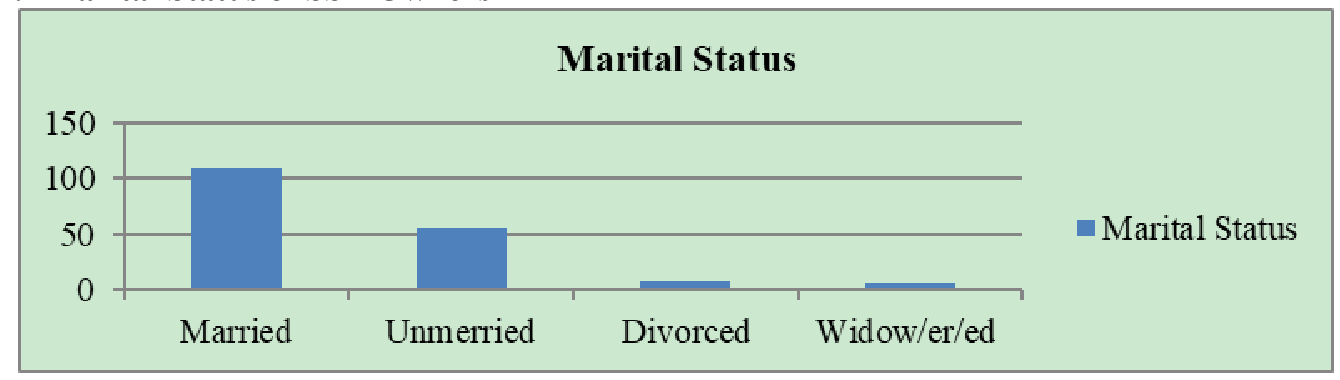

Source: Own survey (2018)

The result of the data analysis shown in the above figure indicates that the majority $112(62.2 \%)$ respondents are married, and $54(30 \%)$ of the respondents are unmarried and the remaining respondents (divorced and widower/ed) are few in number in the sample survey.

Table 1:- Time Range of Establishment

\begin{tabular}{|l|c|c|}
\hline \multicolumn{1}{|c|}{ Time range of establishment } & Number & Percent \\
\hline Before 2000 G.C & 0 & $0 \%$ \\
\hline Between 2000 G.C and 2005 G.C & 3 & $1.67 \%$ \\
\hline Between 2005 G.C and 2010 G.C & 14 & $7.78 \%$ \\
\hline Between 2010 G.C and 2015 G.C & 40 & $22.22 \%$ \\
\hline After 2015 & 123 & $68.33 \%$ \\
\hline Total & 180 & $100 \%$ \\
\hline
\end{tabular}

\section{Source: Own survey (2018)}

The result of the data analysis presented in the above table show that $123(68.33 \%)$ of the small scale businesses on both district (Dolo ado and Filtu) have short recorded history of experience in performing their activities and they are recently established businesses. On the other hand the next largest number $40(22.22 \%)$ of the small scale business have started their business between 2010 G.C and 2015 G.C and there is no Small scale 
businesses that started their activities before 2000 G.C in both district.

Chart 2:- Availability of Infrastructure

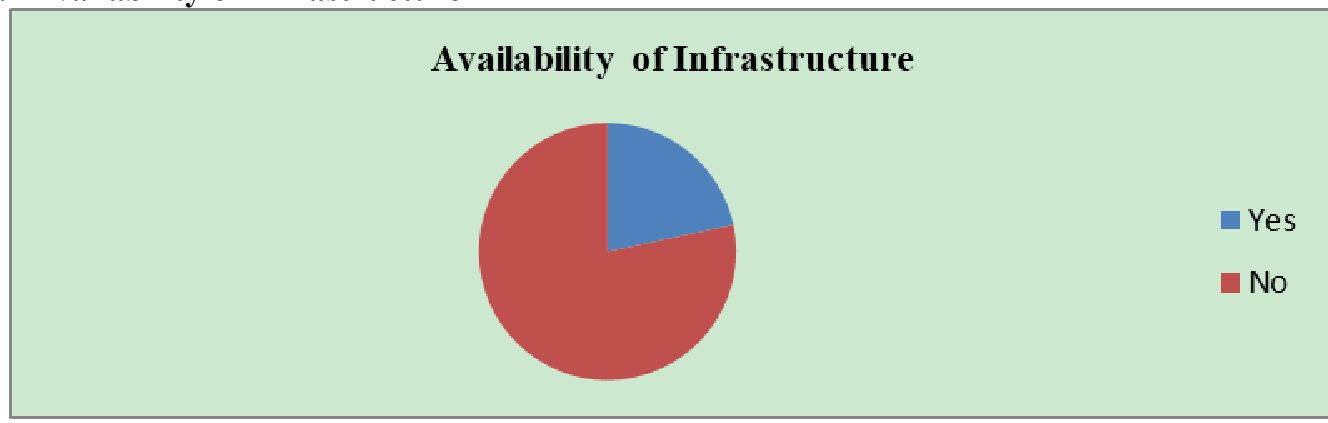

Source: Own survey (2018)

The availability of infrastructure facilities is the major and crucial factor for operations and development of Small scale businesses. The result of data analysis presented in chart 2, shows that $141(78.33 \%)$ of the respondents in both district said that there no sufficient infrastructure facilities for operating small scale businesses and the rest $39(21.67 \%)$ of the respondents said that there is availability of infrastructure facilities. The implication of the result shows that there is no infrastructure facility for running small scale business in both districts.

Chart 3:- Conducting of cost benefit analysis before establishment

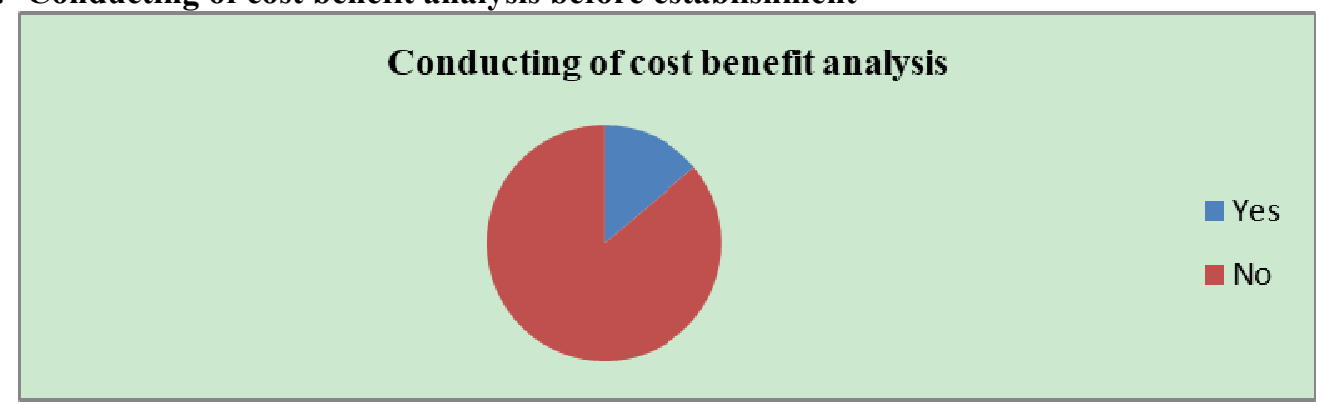

\section{Source: Own survey (2018)}

Before Starting a business, conducting cost benefit analysis or the economic feasibility of business or project is vital for making decision whether to go for operation or not. As shown in chart 3, the majority of the respondents $155(86.11 \%$ ) said that cost benefit analysis was not conducted before the operation of their business and the remaining $25(13.89 \%)$ of the sample size said that the cost benefit analysis was conducted before the operation of small scale business. The result shows that the majority of small scale business owners were not conducting the economic feasibility of the business before they start the operation.

Table 2:- How the business is managed

\begin{tabular}{|l|c|c|}
\hline \multicolumn{1}{|c|}{ Respondent } & Number & Percent \\
\hline Solely by one individual & 132 & $73.33 \%$ \\
\hline By one individual having consultation from others & 37 & $20.56 \%$ \\
\hline By Partnership with others & - & $0 \%$ \\
\hline By families & 11 & 6.11 \\
\hline Total & 180 & $100 \%$ \\
\hline
\end{tabular}

Source: Own survey (2018)

As show in the above table the majority 132 (73.33\%) of the owners indicates that solely one individual. Whereas $37(20.56 \%)$ of the owners show that the owner being supported by consultation from other individual manages their business. This shows that Small scale business management does not require the usual formal management structures used by larger firms and managed by the owner.

Table 3:- Factors affect the Performance of Small Scale Business

\begin{tabular}{|l|c|c|}
\hline \multicolumn{1}{|c|}{ Respondent } & Number & Percent \\
\hline Lack of finance & 102 & $56.67 \%$ \\
\hline Lack of owners motivation & 4 & $2.22 \%$ \\
\hline Lack of initiation and Support from government. & 74 & $41.11 \%$ \\
\hline Absence of worker cooperation & - & $0 \%$ \\
\hline Others & - & $0 \%$ \\
\hline Total & 180 & $100 \%$ \\
\hline
\end{tabular}

Source: Own survey (2018) 
As show in the above table the majority $102(56.67 \%)$ owners of the business said that lack of finance is affecting the small scale business and $74(41.11 \%)$ of the respondent said that there is lack of initiation and Support from government and the rest of the respondent said the employees of small scale business have lack of managerial skills. Thus, this shows that lack of finance is the major factor which affects the performance of small scale business.

Table 4: - Hindrance of the small scale business not to upgrade them to middle and large Scale business.

\begin{tabular}{|l|c|c|}
\hline \multicolumn{1}{|c|}{ Respondent } & Number & Percent \\
\hline Family dependency in the business & 120 & $66.67 \%$ \\
\hline Low profitability of the business & 55 & $30.56 \%$ \\
\hline Low startup capital & - & $0 \%$ \\
\hline Others & 5 & $2.77 \%$ \\
\hline Total & 180 & $100 \%$ \\
\hline
\end{tabular}

Source: Own survey (2018)

As shown in the above table indicates that $120(66.67 \%)$ of small scale business owner believe that the existence of high family dependency on business is as hold back factors not to upgrade the business to middle and large Scale business. Low profitability of the business is the second hindering factor for small scale business not to elevate them to middle and large Scale business. Thus, this indicates that there is high family consumption and dependency in small scale business and this affected the business not promote them to middle and large Scale business.

Chart 4:-Owners and employees managerial skill and entrepreneurial ability

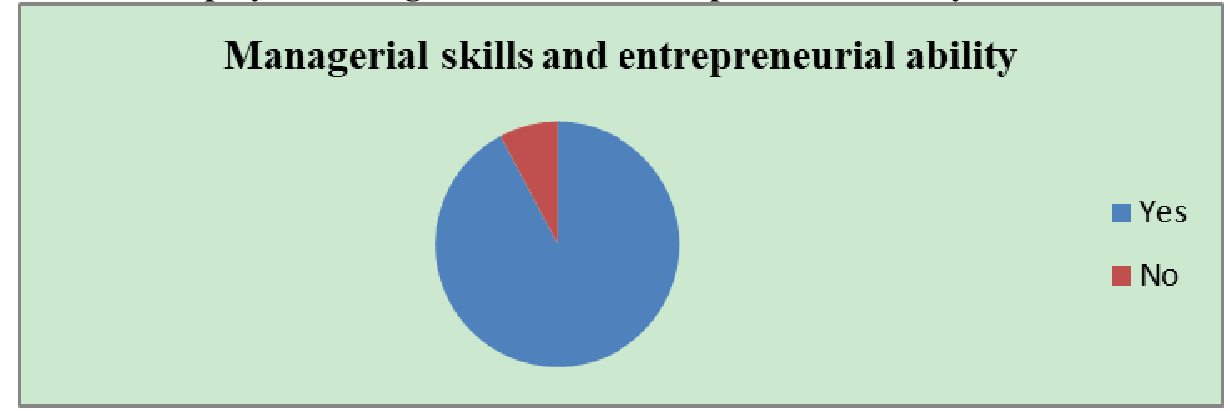

\section{Source: Own survey (2018)}

Managerial skills and entrepreneurial ability are the key factors for successful operation, growth, development and for overall profitability of the business. As indicated in above chart the majority 166(92.22\%) of the owners and employees of small scale business they do not have managerial skills and entrepreneurial Ability and the remaining 14(7.78\%) of them have managerial skills and entrepreneurial Ability. Thus, most of the business owners do not have managerial skills and entrepreneurial Ability to run the operational activities of their business.

\section{Chart 5:- Business Operation is through Planning}

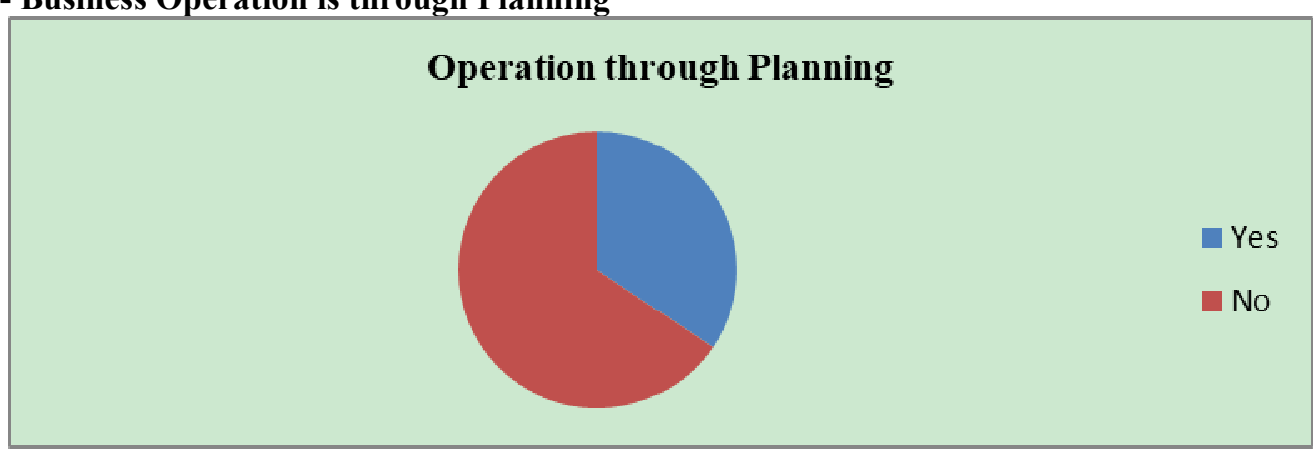

\section{Source: Own survey (2018)}

As indicated in above chart, the majority of the business owners118 (65.66\%) do not use plan to operate their business and the remaining 62(34.44\%) could operate their business through use of plan .Business planning is the key for successful operation, growth, development and for overall profitability of the business. Therefore, most of the business owners do not follow business planning for their operational activities mainly because of lack for ability and skill of make plans. 
Table 5:-Factors affect the profitability of the businesses

\begin{tabular}{|l|c|l|}
\hline \multicolumn{1}{|c|}{ Response } & Number & \multicolumn{1}{c|}{ Percent } \\
\hline Location of the business & 45 & $25 \%$ \\
\hline Labor cost & 6 & $3.33 \%$ \\
\hline Material cost & 4 & $2.22 \%$ \\
\hline Competition of the market & 125 & $69.45 \%$ \\
\hline Absence of goodwill & - & $0 \%$ \\
\hline Others & - & $0 \%$ \\
\hline Total & 180 & $100 \%$ \\
\hline
\end{tabular}

Source: Own survey (2018)

The profit is the primary objective of running business and any business owner expects its operational results to exceed the costs and expenses incurred in the business operation. As indicated in the above table the majority of the respondents $125(69.45 \%)$ said that their business profitability has been affected by high competition of the market and next to that $25(45 \%)$ of the business owners said that the current location of the business is the second factors which highly affected the profitability of their business. As a result, the profitability of the majority business could be affected by high competitions of the market.

Table 6:- Strategies to be strong competitor in market

\begin{tabular}{|l|c|c|}
\hline \multicolumn{1}{|c|}{ Response } & Number & Percent \\
\hline Proper customer service & 48 & $26.67 \%$ \\
\cline { 2 - 3 } Providing of quality Product/service & 22 & $12.22 \%$ \\
\cline { 2 - 3 } Selling at lower prices & 110 & $61.11 \%$ \\
\hline Others & - & $0 \%$ \\
\hline Total & 180 & $100 \%$ \\
\hline
\end{tabular}

Source: Own survey (2018)

Business should give due attention to quality of their product or service, customer service, prices and all needs of customer to be competitive with in market. The result of the data analysis shown in the above table is $48(26.67 \%)$ of the respondents disclosed that they choose to compute through giving proper customer services and $110(61.11 \%)$ of the respondents believe that the provision of selling at lower prices and the remaining of $22(12.22 \%)$ of the respondents choose to compute through provision of quality product and service. The above the result shows that, the business owners give greater weight for lower pricing to get the competitive advantage of the market than quality and proper customer services. This indicates that provisions of commodities with lower prices are more sensitive than provision of quality product or service and proper customer service.

Chart 6:- Availability of sufficient capital to run the business

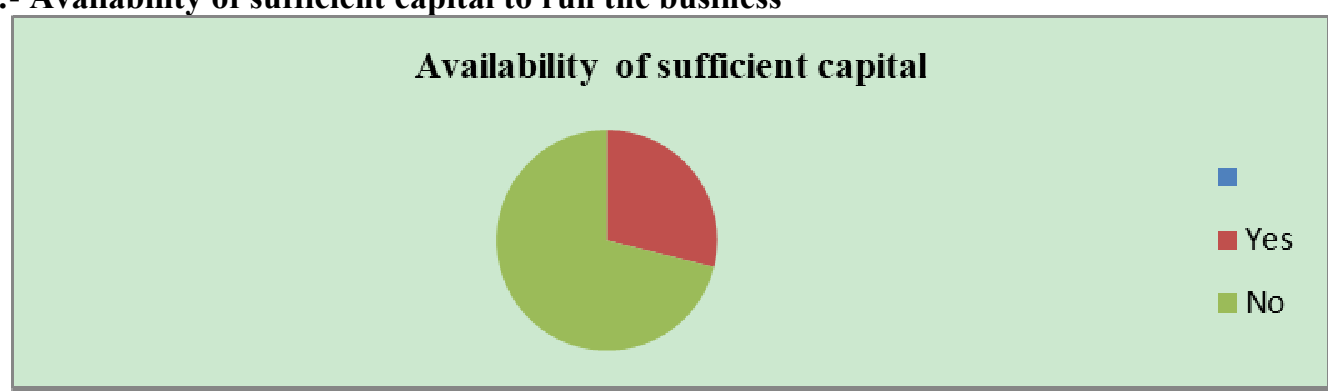

Source: Own survey (2018)

Finance is the life blood of any business. Without finance businesses could not operate their activities. For successful operation, businesses need to have sufficient capital. The result of the data analysis shown in the above chart indicates that $128(71.11 \%$ ) of the respondents have the problem of capital for operation of their businesses and $52(28.89 \%)$ of the respondents stated that their available fund is adequate to carry out their operational activities. This indicates that the majority of the business owners are in problem with shortage of capital to run their businesses. 
Table 7:- Startup capital at the time of establishment of the business (initial capital)

\begin{tabular}{|c|c|c|}
\hline Response & Number & Percent \\
\hline $1000-10,000$ & 33 & 18.33 \\
\hline $10,001-20,000$ & 102 & 56.67 \\
\hline $20,001-30,000$ & 22 & 12.22 \\
\hline $30,001-40,000$ & 14 & 7.78 \\
\hline$>40,001$ & 9 & 5 \\
\hline Total & 180 & $100 \%$ \\
\hline
\end{tabular}

Source: Own survey (2018)

As the data analysis of the table shows $102(56.67 \%)$ of the respondents indicated that their initial capital at the time of starting the business which range of $10,001-20,000$ birr. 33(18.33\%) and 22(12.22\%) of the respondents witnessed that they started business with in initial capital which in within the range of birr $1000-$ 10,000 and birr 20,001-30,000 respectively. The remaining $9(5 \%)$ of the respondents disclosed that they began operation of their business with an initial capital of greater than birr 40,001 where at the rest $14(7.78 \%)$ of the respondents started the business operation with an initial capital range of birr 30,001 - 40,000.

Table 8:- What financing methods are used?

\begin{tabular}{|l|l|c|}
\hline \multicolumn{1}{|c|}{ Response } & Number & Percent \\
\hline Borrowing form bank & 2 & $1.11 \%$ \\
\cline { 2 - 3 } $\begin{array}{l}\text { Borrowing from peers } \\
\text { Grant from Micro-finance office }\end{array}$ & 75 & $41.67 \%$ \\
\hline \multicolumn{1}{|c|}{ Others } & 180 & $52.78 \%$ \\
\hline Total & $10.44 \%$ \\
\hline
\end{tabular}

Source: Own survey (2018)

As indicated on the above table, $95(52.78 \%$ ) of the respondents witnessed that their source of finance micro-finance office, next to this for $75(41.67 \%)$ of business owners their source of finance is their peers and the remaining $2(1.11 \%)$ and $8(4.44 \%)$ used as their source of finance borrowing from bank and others source respectively. The large business can be financed through various methods of borrowing from bank. Small scale businesses are not expected to generate a satisfactory profit for a given period and the income generated to the growth of the business may even remain insignificant in most case. As indicated in the above table, almost all business does not have the possibility to borrow finance from bank and their major source is fund from microfinance office.

\section{Chart7:- Existence of government emphases and support for small scale businesses}

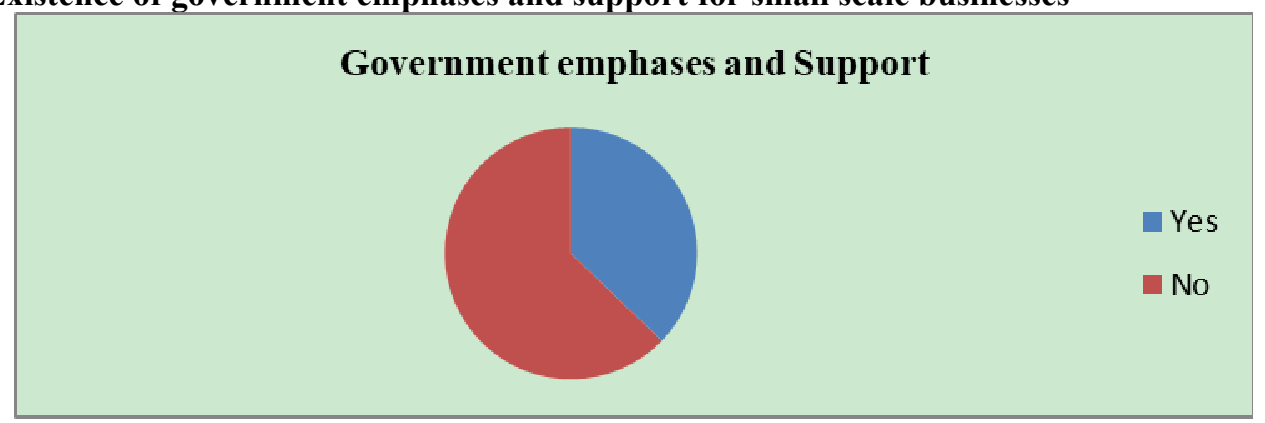

Source: Own survey (2018)

The result of the data analysis shown above depicts that $13(62.78 \%)$ of the respondents disclosed that there is no emphases and support for small scale business from the government side and the remaining 67(37.22\%) of the respondent said there is emphases and Support from government for small scale businesses. Here as depicted in the above table, there is no support for business owners from government. 
Chart 8:-Impact of government on small scale business

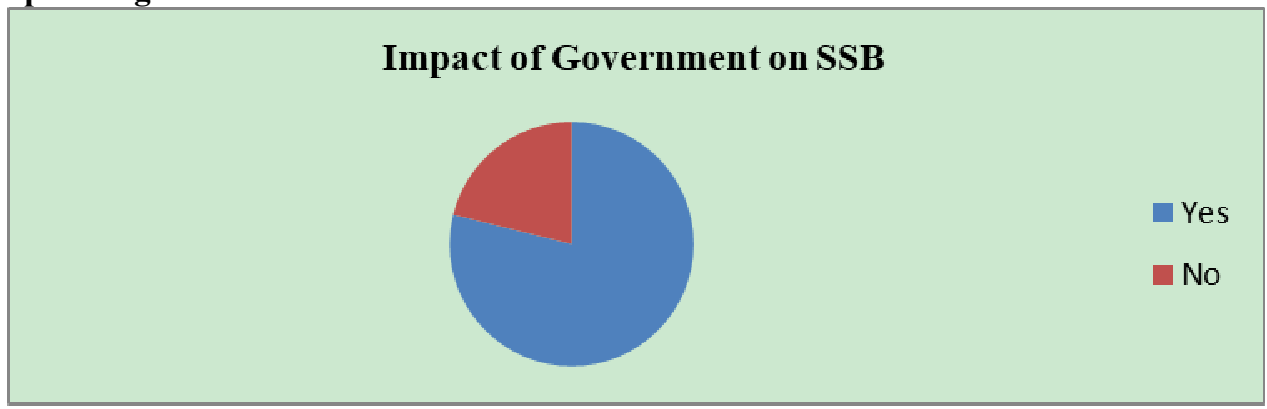

Source: Own survey (2018)

As depicted on the above table,142(78.89\%) of small scale business owners said that there is influence on the business from the government side and the impact of the government can be through charging of high taxation both existing and newly starting business. However, the remaining 38(21.11\%) of the respondents said there is no influence on their business from government.

Table 9:-Problem of small scale business

\begin{tabular}{|l|l|c|}
\hline \multicolumn{1}{|c|}{ Response } & \multicolumn{1}{c|}{ Number } & Percent \\
\hline Lack of adequate finance and Supporting agencies & 103 & $57.22 \%$ \\
\cline { 2 - 3 } $\begin{array}{l}\text { Lack of work place } \\
\text { High house rent }\end{array}$ & 65 & $36.11 \%$ \\
\hline Others & 12 & $6.67 \%$ \\
\hline Total & 180 & $0 \%$ \\
\hline
\end{tabular}

Source: Own survey (2018)

The data analysis shows that the problem of small business indicates that $103(57.22 \%)$ of the respondents said that lack of adequate finance and absence of appropriate supporting agencies are the major problems. Such as training, information and consultation should not be given for small scale business from agencies side and the other $65(36.11 \%)$ and $12(6.67 \%)$ of business owners said that there is a problem for work place and high cost of house rent for small scale businesses respectively. As depicted in the above table, lack of finance and absence of supporting agencies as well as lack of work places are the major problems of small scale business in Ethiopia Somali region at Liban zone (specifically in dolo ado and filtu district). As a result the owners of the businesses in both districts are in need of support from government bodies in order to solve their problems.

\section{Finding, Conclusion and Recommendations}

\subsection{Finding}

There are many businesses with in the Ethiopia but this research conducted on assessment of factors affecting the enactment of small scale businesses within pastoral community in Ethiopia Somali region at Liban zone (specifically in dolo ado and filtu district).The research tried to find the full information for small scale by using methodology like data collection tools (i.e. questionnaires), secondary sources, Purposive sampling technique and data analysis like, Charts, table and percentage.

From the study it was found that $135(75 \%)$ of the business owners are male and $45(25 \%)$ of them are female. Majority of the business owners are male. The majority (85) 47.2\% respondents lie within the age category of 36 to 50 years. As Shown in the data analysis, the majority 112(62.2\%) small scale business owners are married, and $54(30 \%)$ of the respondents are unmarried and the remaining respondents are divorced and widower/ed. The majority $123(68.33 \%$ ) of the small scale businesses on both district (Dolo ado and Filtu) have short recorded history of experience in performing their activities and they are recently established businesses. The availability of infrastructure facilities is the major and crucial factor for operations and development of Small scale businesses. As shown in the data analysis the majority $141(78.33 \%)$ of the respondents in both district said that there is no sufficient infrastructure facilities for operating small scale businesses. The finding of data analysis shows that the majority $155(86.11 \%$ ) of Small scale business owners said that cost benefit analysis was not been conducted before the operation of their business. The Study shows that the majority $132(73.33 \%)$ of the businesses have been owned by solely one individual. Based on the response of 102(56.67\%), lack of finance is the major factors that affect the performance of small scale businesses. From the total respondent, the majority $120(66.67 \%)$ of small scale business owner believed that the existence of high family dependency on the business is a hold back factors not to upgrade them in to the middle and large Scale businesses. Managerial skills and entrepreneurial ability are the key factors for successful operation, growth, development and for overall profitability of the business. However, according to the finding the majority $166(92.22 \%)$ of the owners and employees of small scale business they do not have managerial skills and entrepreneurial ability to run their 
businesses. The majority of the business owners118 (65.66\%) do not use plan to operate their business. According to the majority response $125(69.45 \%)$, the profitability of the businesses have been affected by high competition of the market. from the total respondents $110(61.11 \%)$ of the respondents confirmed that, they use as a strategy lowering the prices of commodities and Services in order to be strong competitor in market. The result of the study indicated that the majority $128(71.11 \%)$ of small scale owners are in problem of capital for the operation of their businesses. As indicated on the data analysis part, 95(52.78\%) of the respondents witnessed that they use as source of finance micro-finance office. The majority $113(62.78 \%)$ of the respondents disclosed that there is no emphases and support for small scale business from the government side. The majority $142(78.89 \%)$ of small scale business owners disclosed that there is influence on their business from the government side and the impact of the government can be through charging of high taxation both existing and newly starting business. As indicated on the data analysis lack of adequate finance and absence of appropriate supporting agencies are the major problems for small scale businesses in Ethiopia Somali region at Liban zone (specifically in dolo ado and filtu district).

\subsection{Conclusion}

As depicted on the data presentation, analysis and interpretation, the following conclusions have been forwarded by the researcher. The finding of this research showed that the majority of small scale business owners are males and young in age. All most all business owners are married. The majority of the businesses have short recorded history of experience in performing their activities and they are recently established businesses. Absences of sufficient infrastructure facilities are the major factor for operations and development of Small scale businesses. The majority of small scale business owners on both district (dolo ado and filtu) could not use cost benefit analysis before the operation of their businesses. The Study shows that the majority of the businesses have been owned by solely one individual. Lack of finance is the major factors that affect the performance of small scale businesses. The existence of high family dependency on the businesses has been observed a hold back factors for small scale businesses not to upgrade themselves to the middle and large Scale businesses. As depicted on the finding the owners and employees of small scale business have no managerial skills and entrepreneurial ability to run their businesses. The Research showed that, high competition of the market was the major factors that affect the profitability of the businesses. The owners of small scale businesses use lowering the prices of commodities and Services as a strategy in order to be strong competitor in market. The result of the study indicated that small scale owners are in problem of capital for the operation of their businesses. The microfinance office has been used for the majority of Small scale businesses as source of finance. The owners of the businesses disclosed that there is no emphases and support for small scale business from the government side. There is influence on the businesses from the government side and also high taxation both on existing and newly started businesses. Lack of adequate finance and absence of appropriate supporting agencies are the major problems for small scale business

\subsection{Recommendation}

From the investigation, I the researcher recommend that:-Since the businesses have a short recorded history of experience and they are recently established businesses, the government and agencies of the area, should advised to give them capacity building training on managerial skills and entrepreneurial ability in order to enhance their confidence and knowhow in performing their businesses. The businesses owners are in problem of infrastructure facilities. Hence, the Government of Ethiopia Somali region specifically the Liban zone should advised to alleviate such kind of problem for Small scale businesses so as to improve their operations and development of the businesses. To solve the financial shortage of small scale businesses the owners of the businesses would advise to prepare two strategies. First, they recommended to control their expenditures and next, lobbing the government in order to establish well credit association in the area. Before the operation of the businesses, making cost benefit analysis and checking for the worthiness and Continuity for businesses are compulsory activities. Hence, the government of the areas and agencies has a role in awareness creation for existing and newly establishing businesses in order to implement cost benefit analysis on their businesses. To improve and upgrade the Small scale businesses to middle and large Scale businesses, the owners of small scale businesses should have to use the alternative sources of income to alleviate the family dependency on current small scale businesses. To be strong competitor in the market, rather than lowering only the price, in addition, it is better for small scale businesses to compute by providing the right quality of goods and services at right time and at right place. The owner of the businesses uses micro-finance as their major sources of finance. In addition to this they are recommended to diversify their alternatives sources of finance through using banks, peers and traditional lending institutions. Since high taxation has been observed as a major factor, the government of Ethiopia Somali region specifically Liban zone would advise to collect fair tax from the existing business owners and to tolerate for newly established businesses (starters) for some period of time until their business become financially strong. 


\section{References}

1. Arinaitwe, J.K. (2006). Factors Constraining the Growth and Survival of Small Scale Businesses: Developing Countries analysis, Journal of American Academy of Business, Cambridge, Vol. 8 No. 2, pp.167-78.

2. Armstrong, M. (1994). Human Resource Management Practice, Replika Press Ltd, India.

3. Assegedech Woldelul. (2004). Marketing Strategies for Micro and Small Enterprises in Ethiopia: Ethiopian Business Development Services Network (EBDSN), Addis Ababa.

4. Ayyagari, Meghana., Thorsten Beck, AsliDemirgücKunt (2003), "Small and Medium Enterprises Across the Globe", World Bank Policy Research Working Paper 3127, August, Washington D.C.

5. Enock Nkonoki. (2010). what are the factors limiting the success and/or growth of small businesses in Tanzania?-An empirical study on small business growth; Arcada University of Applied Sciences, Tanzania.

6. Faiza, M. \& Jamal, T. (2009). Temporal Population Growth of Lahore. Journal of Scientific Research, 1, 53-58.

7. Federal Democratic Republic of Ethiopia Ministry of Trade and Industry Micro and Small Enterprise Development Strategy, 2004, Addis Ababa, Ethiopia.

8. Small Business Administration. (2003). Definition of Small Business in the United S States: Frequently Asked Questions.US Small Business Administration (http:// www.sba.gov/faqs/).

9. Sule, E.I.K. (1986). Small-Scale Enterprises in Nigeria: Concepts, Appraisals of some Government Policies and Suggested Solutions to Identified Problems.

10. Economic and Financial Review. Central Bank of Nigeria, Vol. 24/4, pp.24.

11. Trulsson, P. (1997). Strategies of entrepreneurship: Understanding industrial entrepreneurship and structural change in Northern Tanzania. Linkoping, Sweden.

12. Ajayi, O.A. (2002). Development of Small-Scale Enterprises in Nigeria. Being Paper Presented at Workshop on Grassroots Advocacy and Economic Development. September 11-13.

13. Anamekwe, C. (2001). Micro and Small-Scale Enterprises in Nigeria: Problems and Prospects. Being paper presented at Workshop on Grassroots Advocacy and Economic Development. September 11-13.

14. Bark ham, R. (1992). 'Entrepreneurial Characteristics and Size of the New firm: A Model and Econometric Test', paper presented at the international conference on birth and start-up of small firms. Milan, Bocconi University.

15. Barkham, R., Gudgin, G., Hart, M. and Hanvey, E. (1996).The Determinants of Small Firm Growth, London: Jessica Kingsley Publishers Ltd.

16. Cheah, H.B. and Cheah, M. (2005). Small, diversified and sustainable: small enterprises in a Sustainable production system. Sustaining growth and performance in East Asia,Cheltenham: Edward Elgar, pp. 28

17. Courseault Trumbach, C., Payne, D. and Kongthon, A. (2006). Technology mining for small firms: Knowledge prospecting for competitive advantage. Technological Forecasting \& Social Change, Vol. 73, pp. 937-949.

18. Hailay Gebretinsae: Entrepreneurship and Small Business Management (2nd Edition).

19. Hodgetts, RichardM.Kurakto, DonaldF(1998):Entrepreneurship: A contemporary approach (fourth Edition).

20. HirshRobert D. and D. and PetersMichaelP(2002): Entrepreneurship (5 $5^{\text {th }}$ Edition).

21. Holt David H. (2000): Entrepreneurship: new venture Creation "Eastern Economy Edition.

22. Helen G/tinsae (2003): Entrepreneur ship and small-business Management.

23. Jim Dew Horst and Pual Burns (1993): Small-business management.

24. Merer, Harris and Retil: Marketing, $8^{\text {th }}$ Edition page 500-505.

25. David Deakin's FRSA (1999): small-business management ( $2^{\text {nd }}$ Edition).

26. David H.Hort (1992): entrepreneurship and new venture creation.

27. Trainers Guide manual (Nov.2002): small-business growth strategies.

28. Martin Christopher (1995): small-business management: page 102-108. 